\title{
Ksztaltowanie zabudowy mieszkaniowej wpisującej się w zasady ochrony terenu i pozyskiwania rezerw przestrzeni
} we współczesnym mieście

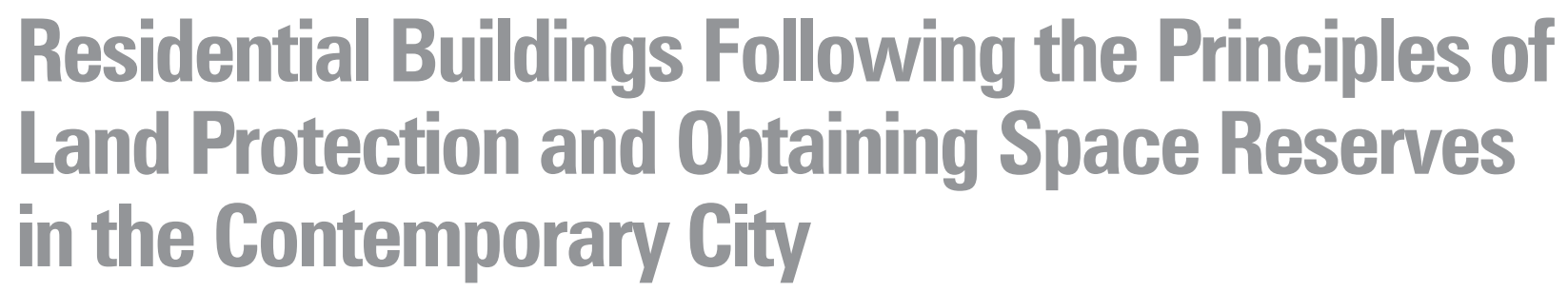

\section{Streszczenie:}

Celem pracy jest zaprezentowanie problemów architektoniczno-urbanistycznych związanych z kształtowaniem zabudowy mieszkaniowej zharmonizowanej ze środowiskiem naturalnym w obliczu postępujących na świecie i w Europie procesów urbanizacji i degradacji tego środowiska. Skoncentrowano się na wyodrębnieniu działań na rzecz zrównoważonego modelu życia w mieście, a szczególnie na rozwiązaniach służących ograniczania kosztów urbanizacji. Należą do nich, m.in. koncepcje kształtowania zabudowy mieszkaniowej podporządkowane ochronie terenu i pozyskiwaniu wszelkich jego rezerw w istniejącej miejskiej zabudowie. Przedstawione przykłady wpisują się w idee rozwoju miasta na zasadzie ekosystemu oraz promowane współcześnie procesy służące reurbanizacji.

\begin{abstract}
:
The objective of this paper is to present architectural and urban issues associated with the process of shaping residential buildings in harmony with the natural environment, in light of processes of urbanisation and degradation of this environment progressing in Europe and globally. The material focuses on identifying activities fostering a sustainable model of life in the city, in particular on solutions aiming at the limitation of urbanisation costs.

These are - without limitations - concepts of designing residential buildings with respect for land protection and aiming to obtain all possible land reserves in the urban landscape. They fit in the concepts of urban development based on the principles of an ecosystem, as well as processes fostering reurbanisation, promoted today.
\end{abstract}

Słowa kluczowe: Architektura, urbanistyka, miasto ekologiczne, miasto zrównoważone, reurbanizacja,

Keywords: Architecture, urban planning, urban space, urban design, ecological city, sustainable city, re-urbanization

\section{Wprowadzenie}

Analiza tendencji w transformacji przestrzeni miast europejskich w ostatnich dekadach pozwala na sformułowanie wniosku, że stanęły one obecnie w obliczu nowych wyzwań w związku z przemianami zachodzącymi w procesach urbanizacji, a także zmianami demograficznymi, w tym szczególnie dotyczącymi struktury mieszkańców. Przeciwdziałanie niekorzystnym zjawiskom związanym z rozwojem miast stanowi w ostatnich latach przedmiot szerokiej debaty na forum europejskim. Zmierza ona do określenia priorytetowych celów strategicznych związanych z polityką społeczną oraz gospodarczą i przestrzenną. Znajduje też odzwierciedlenie w powstających w poszczególnych krajach dokumentach i aktach prawnych. Europa należy do najbardziej zurbanizowanych kontynentów. W jej miastach żyje blisko 80 \% mieszkańców (Miasta przyszłości. Wyzwania, wizje, perspektywy, Komisja Europejska, Dyrekcja Generalna ds. Polityki Regionalnej, 2011, s.14)1. Tak liczna ich koncentracja na wspólnym terytorium tworzy problemy, a jednocześnie

\section{Introduction}

An analysis of tendencies present in transformations of space in European cities in recent decades allows to conclude that today they face new challenges in connection with transformations of urbanisation processes, as well as demographic changes, including changes pertaining to the structure of city residents. In recent years, fighting unfavourable phenomena associated with urban development has constituted a subject matter of a wide debate on the European forum. It aims at the determination of priority strategic goals connected with the social, economic, and spatial policy. It is also reflected in documents and legal acts implemented in individual countries. Europe belongs to the most urbanised continents. $80 \%$ of its inhabitants live in towns and cities (Miasta przyszłości. Wyzwania, wizje, perspektywy, Komisja Europejska, Dyrekcja Generalna ds. Polityki Regionalnej, 2011, s. 14) 1 . Europe belongs to the most urbanised continents. $80 \%$ of its inhabitants live in towns and cities. Such an enormous concertation on one territory gives

* dr hab. inż. arch., Stanisława Wehle-Strzelecka, Prof. PŚk, Wydział Budownictwa i Architektury, Politechnika Świętokrzyska / dr hab. eng. arch. Stanisława Wehle-Strzelecka Prof. PŚk, Faculty of Civil Engineering and Architecture, Kielce University of Technology, https:// orcid.org/0000-0001-6076-7420, e-mail: wehle@o2.pl

** dr inż. arch. Monika Strzelecka-Seredyńska, Wydział Architektury, Politechnika Krakowska / PhD, eng. arch. Monika Strzelecka-

Seredyńska, Faculty of Architecture, Cracow University of Technology, https://orcid.org/0000-0002-9247-0557, e-mail: mstrzeleckaseredynska@o2.pl 
szanse dla wprowadzania innowacyjnych rozwiązań i możliwości działań w sferze architektury i urbanistyki na rzecz przekształcania istniejących struktur miejskich. Przekształcenia te powinny przede wszystkim odnieść się do takich zjawisk społecznych i kulturowych jak gwałtowny rozwój struktur miejskich oraz towarzysząca mu suburbanizacja (urban sprawl) oraz dezurbanizacja ${ }^{2}$. Wymienione procesy zarysowały się już w okresie rewolucji przemysłowej i obserwowane są do dzisiaj zarówno w krajach rozwiniętych jak i rozwijających się (Jakubczyk-Gryszkiewicz, 2012, s. 198). Stanowią wynik poszukiwania przestrzeni dla nowych inwestycji poza intensywnie zabudowanymi obszarami, a także efekt osiedlania się mieszkańców poza miastem w poszukiwaniu lepszego standardu mieszkania w bliższym kontakcie z naturą. Niekorzystnym następstwem wymienionych procesów jest zjawisko depopulacji terenów śródmiejskich oraz presja na ekosystemy wskutek pochłaniania obszarów przyrodniczych na rzecz wprowadzania zabudowy mieszkaniowej o niskiej intensywności. Niekorzystnym efektem jest też rozbudowa systemu usług, w tym sieci transportu zbiorowego i indywidualnego.

Postępujący proces stałego rozrastania się dużych miejskich struktur uświadamia zatem zachodzenie zmian w klasycznym rozumieniu pojęcia miasta, którego obraz, postrzegany przez wieki, rysował się jako zwarty terytorialnie organizm otoczony strefami terenów przyrodniczych. Pojęcie miasta obejmuje dzisiaj już nie tylko konwencjonalne, zwarte miejskie organizmy. Mieszczą się w nim również bardziej złożone układy przestrzenne tworzące wspólnie sieci i pasma połączone liniami transportu (Nowa Karta Ateńska. Wizja miast XXI wieku, 2003, s.24). Przykładem, wśród wielu, może być holenderskie Randstad, a w Polsce m.in. Trójmiasto, miasta na Śląsku.

Odwrotność omówionych wyżej niekorzystnych procesów stanowi, obserwowane równolegle w miastach świata, zjawisko depopulacji, a w konsekwencji zahamowanie ich rozwoju i zanikanie (shrinking cities). Wiąże się to z postępującym starzeniem się społeczeństw, a także spadkiem liczby mieszkańców wskutek opuszczania miast przez młodszą generację. Zjawisko to, znane już z historii urbanistyki, widoczne jest obecnie w USA (Buffalo, Cleveland, Detroit, Pittsburg, St. Louis, Baltimore, Philadelphia) oraz w miastach Europy, w tym również w Polsce (konurbacja katowicka, Bytom, Sosnowiec).

Zatem za priorytetowe zadanie w zakresie polityki miejskiej należy uznać konieczność powstrzymania wymienionych wyżej, negatywnych procesów, w tym gwałtownych i niekontrolowanych procesów urbanizacyjnych, a także zjawiska suburbanizacji i dezurbanizacji oraz kurczenia się i zanikania miast. Należy jednak zaznaczyć, że procesy te mają bardzo zróżnicowany i indywidualny charakter w poszczególnych krajach. Nie istnieje zatem jedyna i dominująca wizja określająca optymalny kierunek rozwoju w jakim powinny podążać współczesne miasta. Na świecie i w Europie obserwuje się obecnie różne modele rozwiązań, a także różne nurty poszukiwań w tym zakresie. Ogólnie można przyjąć, że wpisują się w dwie zasadnicze koncepcje: eko-miasta (Ekopolis) i miasta zrównoważonego.

\section{Możliwości ograniczania kosztów urbanizacji i pozyskiwania przestrzeni dla mieszkania $\mathrm{w}$ istniejącej miejskiej zabudowie}

Rozwijane od kilku dziesięcioleci idee eko-miast i miast zrównoważonych mają na celu ograniczanie kosztów rise to problems, and at the same time offers a chance to introduce innovative solutions and opportunities in the field of architecture and urban planning in favour of transformations of existing urban structures. Such transformations should most of all refer to such social and cultural phenomena as rapid development of urban structures, as well as suburbanisation (urban sprawl) and deurbanization, two phenomena that accompany it ${ }^{2}$. These processes were already visible during the industrial revolution, and have been observed to this day, both in developed and developing countries (Jakubczyk-Gryszkiewicz, 2012, p. 198). They constitute a result of the search of space for new investments beyond heavily built-up areas, as well as an effect of residents settling outside cities in pursuit of better standards of living in a closer contact with nature. An unfavourable consequence of the processes listed above is the phenomenon of depopulation of inner cities and pressure on ecosystems caused by absorption of natural areas for the purposes of low-intensity residential developments. Another unfavourable effect is also the development of the system of services, including public and individual transport networks.

Therefore, the progressing process of expansion of big urban structures makes one aware of changes in the classical understanding of the term 'the city', whose image, perceived through the ages, resembled a territorially compact organism surrounded by zones of natural areas. Today the term 'city' comprises not only conventional compact urban organisms. It also covers more complex spatial layouts, which together form networks and belts linked by means of transport lines (New Athens Charter. Vision of $21^{\text {st_ }}$ Century Cities, 2003, p. 24). One of many examples in this respect can be Randstad in the Netherlands, and in Poland - the Tricity and cities in Silesia.

On the other pole of the unfavourable processes discussed above is the phenomenon of depopulation, simultaneously observed in towns and cities globally, and consequently the process of hampering their development and shrinking cities. This in turn is associated with progressing aging of societies, as well as a drop in numbers of residents due to younger generations leaving their cities. This phenomenon, known already in the history of urban planning, is currently visible in the USA (Buffalo, Cleveland, Detroit, Pittsburgh, St. Louis, Baltimore, Philadelphia), as well as in European cities, including Poland (the Katowice conurbation, Bytom, Sosnowiec).

Therefore, what should be recognised as a priority task in the urban policy is the need to stop the aforementioned negative processes, including those of rapid and uncontrolled urbanisation, as well as the phenomena of suburbanisation, deurbanisation, and shrinking and disappearing of cities. It should be pointed out, however, that these processes have a very diversified and individual character in individual countries. Thus, there is no one dominating vision that would determine an optimal direction of development that contemporary towns and cities should pursue. Currently, different models of solutions and different trends in pursuits in this respect are observed globally and in Europe. In general, it can be assumed that they all fall into two fundamental concepts: eco-cities (Ecopolis), and sustainable cities.

2. Possibilities of limiting costs of urbanisation and obtaining residential spaces in existing urban developments

The concepts of eco-cities and sustainable cities, which have been developing for several decades now, 
środowiskowych związanych z procesami urbanizacji. Ukierunkowują rozwój miast na poszukiwanie form zabudowy otwartych na przyrodę i oszczędnych w odniesieniu do naturalnych bogactw, a jednocześnie dostosowanych do oczekiwań mieszkańców związanych z kulturą dobrego życia. Wpisują się w nie, m.in. koncepcje zielonych miast (green urbanism), miast "dobrego życia"- powolnego (Cittaslow), miast zwartych formowanych na wzór średniowiecznych organizmów miejskich, miast inteligentnych (Smart City), uniwersalnych i przyjaznych wszystkim mieszkańcom, a także rozwijane nadal idee nowego urbanizmu, w tym współczesne interpretacje kontynuujące bardzo już długie tradycje miast-ogrodów ${ }^{3}$. Poszukuje się też dróg podejścia do miasta jako miejsca rewitalizacji przyrodniczej, które harmonijnie łączy środowisko zurbanizowane ze środowiskiem naturalnym. Szczególnie atrakcyjna, z uwagi na założenia ekorozwoju i rozwoju zrównoważonego, wydaje się koncepcja tworzenia sieci małych miast, które podtrzymują swoje tradycje i rozwijają działania prospołeczne i chroniące środowisko naturalne.

Zarówno w odniesieniu do małych jak i większych struktur miejskich optymalne, z uwagi na oszczędną gospodarkę terenem i pozyskiwanie wszelkich rezerw przestrzeni na rzecz programu mieszkaniowego, wydają się działania związane z reurbanizacją (ochrona terenu, rozwój "do wewnątrz"). Mają na celu powrót mieszkańców z suburbiów, aktywizację i ożywienie terenów śródmiejskich poprzez promowanie atrakcyjnych, szczególnie dla rodzin z dziećmi oraz seniorów, form mieszkania. Na podstawie studiów przypadku zaliczono do nich koncepcje architektoniczno-urbanistyczne nastawione na rozwój miast "do wewnątrz", które cechuje:

- formowanie zwartych, energooszczędnych, intensywnych form nowej zabudowy wprowadzanych do istniejącej tkanki, a także sanacja istniejącej zabudowy w drodze adaptacji do funkcji mieszkaniowej przeznaczonej dla różnych grup wiekowych,

- innowacyjność form i lokalizacji (np. mieszkanie na sztucznych wyspach na wodzie, na polderach, pod terenem lub zagłębione częściowo w terenie) ${ }^{4}$,

- różnorodność struktur i form mieszkania, w tym łączących różne generacje (recykling przestrzeni, działania uzupełniające istniejącą zabudowę w mikroskali)

- odzyskiwanie terenów wewnątrzmiejskich w celu wprowadzania proekologicznych oraz zrównoważonych (społecznie i w odniesieniu do przyrody) zespołów mieszkaniowych, m.in. w procesach rewitalizacji (recykling przestrzeni, działania w makroskali) ${ }^{5}$.

W ramach pierwszej grupy rozwiązań uwage zwracają osiągnięcia Holandii- państwa o jednej z najwyższych w Europe gęstości zaludnienia (bardzo liczne przykłady ekologicznych, energooszczędnych i zrównoważonych osiedli i miast, m.in: zabudowa Borneo-Sporenburg w Amsterdamie, w Almere, osiedla Nieuwland, Kattenbroek i Vathorst w Amersfort, prace grupy MVRDV -m.in. Metacity/Datatown (Wehle-Strzelecka, 2018, vol. 174).

Realizacji zaliczanych do pierwszej wyżej wymienionej grupy rozwiązań powstało bardzo wiele również w innych miastach europejskich. Wspomnieć można m.in. o doświadczeniach austriackich. Wymienić tu można: Solar City w Linzu, wiedeńskie realizacje przy Brünnerstrasse, Hofjägerstrasse, Roschégasse oraz Müllnermaisgasse, energooszczędne osiedla w Grazu przy: Nordberggasse, Rettenbacherstrasse, Peterstalstrasse, Bergstrasse, Andritzer Reichstrasse (Wehle-Strzelecka, 2014, s. 164) ${ }^{6}$. aim to limit environmental costs associated with urbanisation processes. They direct the development of towns and cities towards the search of development open to nature and efficient in terms of natural resources, and at the same time meeting residents' expectations connected with the good life culture. They comprise - without limitations - concepts of green cities (green urbanism), cities of good, slow life (Cittaslow), compact cities, moulded according to the pattern of medieval urban organisms, smart cities, universal and friendly to all residents, as well as still developed ideas of new urbanism, including contemporary interpretations continuing very long traditions of garden cities ${ }^{3}$. There are also pursuits of ways of approaching the city as a place of natural revitalisation, which harmoniously blends the urbanised environment with the natural one. A concept which seems to be particularly attractive due to the principles of eco-development and sustainable development is the concept of creating networks of small towns, which maintain their traditions and undertake pro-social measures and actions protecting the natural environment.

Measures which seem to be optimal for both smaller and bigger urban structures due to efficient land management and obtaining all spatial reserves possible in favour of the housing programme are the ones associated with reurbanisation (land protection, inward development). Their goal is to convince city dwellers to come back from suburbs, to stimulate and activate inner cities by promoting attractive forms of residence, particularly for families with children and senior citizens. Basing on case studies, such measures were deemed to comprise architectural and urban concepts oriented towards the inward development of cities, which are characterised by:

- Forming compact, energy-efficient, intense forms of new development introduced in the existing tissue, as well as sanitation of existing buildings by means of their adaptation to the residential function addressed to different age groups,

- Innovativeness of forms and locations (e.g.: apartments on artificial islands on the water, on polders, underground or partly underground) ${ }^{4}$,

- Diversity of structures and forms of residence, including the ones linking different generations (space recycling, supplementing existing development in the microscale),

- Reclamation of inner-city areas in order to introduce residential clusters which are pro-ecological and sustainable (socially and with reference to nature), e.g.: in revitalisation processes (space recycling, macroscale measures $)^{5}$.

What attracts special attention in the first group of solutions are achievements of the Netherlands, a state with the population density which is one of the highest in Europe (numerous examples of ecological, energyefficient, and sustainable housing estates and cites, e.g.: Borneo-Sporenburg in Amsterdam, in Almere, housing estates Nieuwland, Kattenbroek, and Vathorst in Amersfoort, works of the MVRDV group, e.g.: Metacity/Datatown (Wehle-Strzelecka, 2018, vol. 174). The first group of solutions is represented by many projects implemented in other European cities, as well. In this respect, it is worth mentioning Austrian experiences, such as Solar City in Linz, projects implemented in Vienna at Brünnerstrasse, Hofjägerstrasse, Roschégasse, and Mülnermaisgasse, energy-efficient housing estates in Gratz at Nordberggasse, Rettenbacherstrasse, Peterstalstrasse, Bergstrasse, Andritzer Reichstrasse (Wehle-Strzelecka, 2014, p. 164). 
Rozwiązania oszczędnościowe, mające na celu ekologiczną sanację istniejącej substancji i dostosowanie istniejącej zabudowy do nowego programu mieszkaniowego, są bardzo liczne. Tu zwracają uwagę, promowane w ostatnim dziesięcioleciu, projekty adaptacji istniejącej zabudowy blokowej do zmieniających się potrzeb mieszkańców, którzy w wieku senioralnym chcą pozostawać nadal w swoim środowisku zamieszkania. Wpisują się one nie tylko w koncepcję "rozwoju miasta do wewnątrz", ale również w idee tworzenia miasta zrównoważonego społecznie i uniwersalnego. Przykładem są m.in. działania na terenie Ommorrd (Kniflats) w Rotterdamie, w Zurychu (kompleks Irchel), a także w Niemczech w Hamm oraz w Berlinie-Hallersdorf (Strzelecka-Seredyńska, 2020, s. 229, 230).

W ramach drugiej grupy wyodrębnionych rozwiązań wymienić można osiedla i domy wznoszone na polderach. Przykładem może być wiele modelowych realizacji w Holandii, m.in. miasto Almere, a także dzielnica EVA Lanxmeer (1994-2009) w Culemborgu („Sustainable Implant").

Kolejny krok w stosunku do realizacji zabudowy na otaczanych wałami polderach stanowią inwestycje powstające na wodzie. Przykładem mogą być „pływające domy” osiedla ljburg w Amsterdamie, realizacje koło Arnhem i w Leeuwarden7. Zaliczyć do nich można również zespół mieszkaniowy dla seniorów "Swinging Apartments", usytuowany na zbiorniku wodnym w centrum dzielnicy IJsselmonde w Rotterdamie, a także w Hadze w Holandii. Wymienione trzy ostatnie przykłady wpisują się również w koncepcję realizowania zasad zrównoważenia społecznego i łączenia mieszkańców należących do różnych pokoleń. Należy tu wspomnieć o powstających futurystycznych projektach autonomicznych jednostek mieszkaniowych (przykład: Ecopolis Lilypad na wodach oceanu).

Do trzeciej grupy rozwiązań (recykling przestrzeni w mikroskali) zaliczyć można obiekty przystosowane do włączania w istniejące budynki. Należą tu wszelkie realizacje uzupełniające istniejącą zabudowę (np. budynki „plombowe"), a także jednostki przystosowane do włączenia w nią
Substance-saving solutions, which aim at ecological sanitation of the existing tissue and adjustment of existing buildings to the new housing programme, are very numerous. In this respect special attention should be paid to projects promoted over the last decade, consisting in the adaptation of existing block developments to the changing needs of residents, who in their senior years wish to remain in their place of residence. Not only do they fit in the concepts of inward development of cities, but they are also in line with the ideas of creating socially sustainable and universal cities. A good example in this respect are measures undertaken in Ommorrd (Kniflats) in Rotterdam, Zurich (the Irchel complex), as well as in Hamm and Berlin-Hallersdorf, Germany (Strzelecka-Seredyńska, 2020, pp.229, 230).

The second group of suggested solutions comprises housing estates and buildings founded on polders. Good examples here could be numerous model projects implemented in the Netherlands, e.g.: the city of Almere, as well as the district of EVA Lanxmeer (19942009) in Culemborg ('Sustainable Implant').

Another step towards building houses on polders surrounded by embankments are investments implemented on water, such as 'floating houses' in the ljburg housing estate in Amsterdam, projects implemented near Arnhem and in Leeuwarden?. One of good examples is the residential complex for senior citizens called Swinging Apartments, located on a body of water in the heart of the district of IJsselmonde in Rotterdam, as well as in the Hague, the Netherlands. The latter three examples are also in line with the concept of implementing social sustainability principles and bringing together residents representing different generations. In this context, one should mention the currently implemented futuristic projects of autonomic residential units (e.g.: Lilypad Ecopolic on the ocean).

The third group of solutions (microscale space recycling) comprises structures adjusted to being incorporated in existing buildings. These are all sorts of projects which constitute additions to the existing development (e.g.: infill buildings), as well as units

il. 1. Zespoły mieszkaniowe o zabudowie zwartej; w Linzu: a - Solar City; w Wiedniu: b- przy Brünnerstrasse, c - przy Hofjägerstrasse; w Culemborgu - d, w ljburg w Amsterdamie: e- „pływające domy”, autor: S. Wehle-Strzelecka

ill. 1. Residential high-density complexes: a. Solar City in Linz; Vienna: b. Brünnerstrasse, c. Hofjägerstrasse; d. Culemborg; e. 'floating houses' in ljburg, Amsterdam; author: S. Wehle-Strzelecka
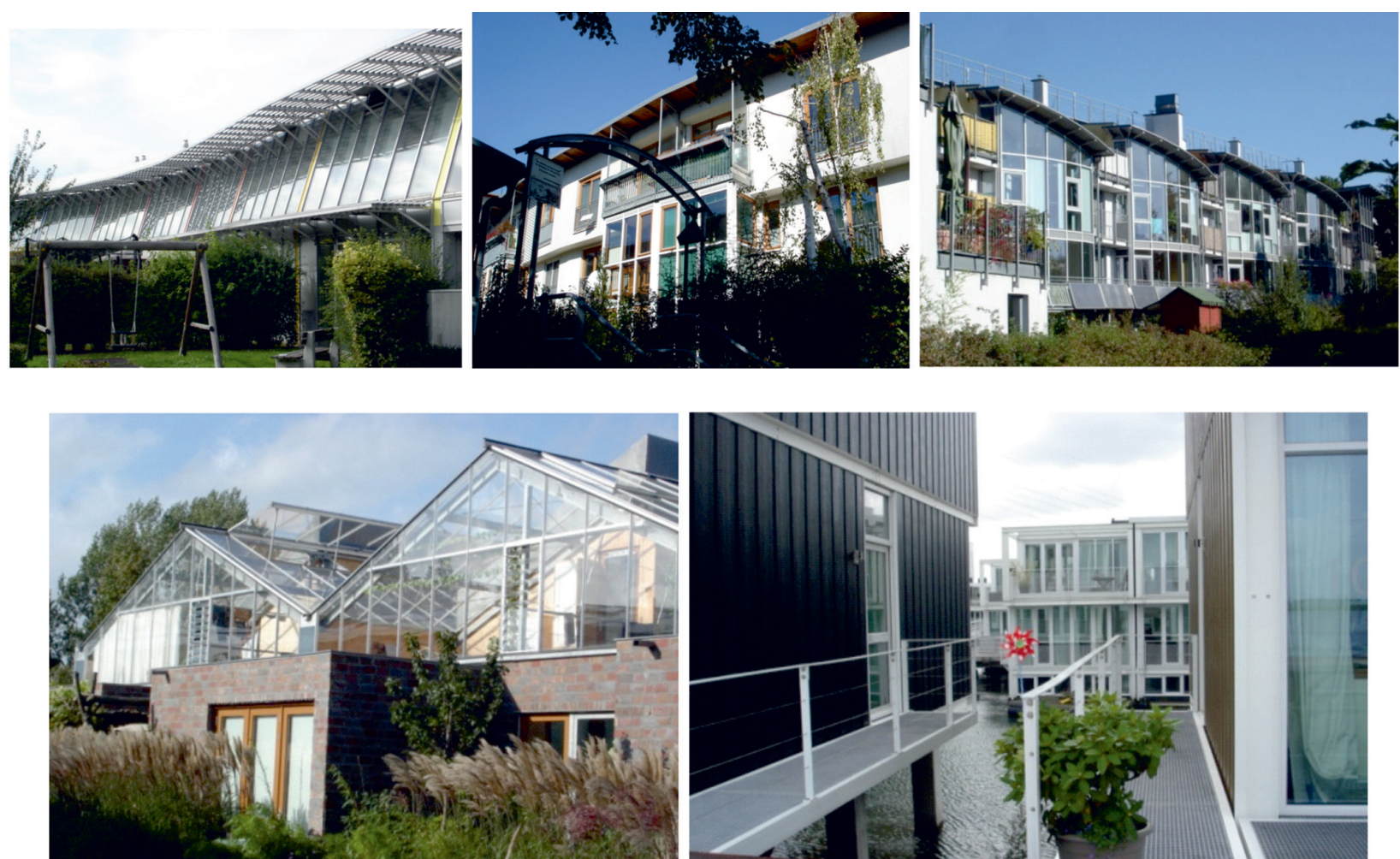

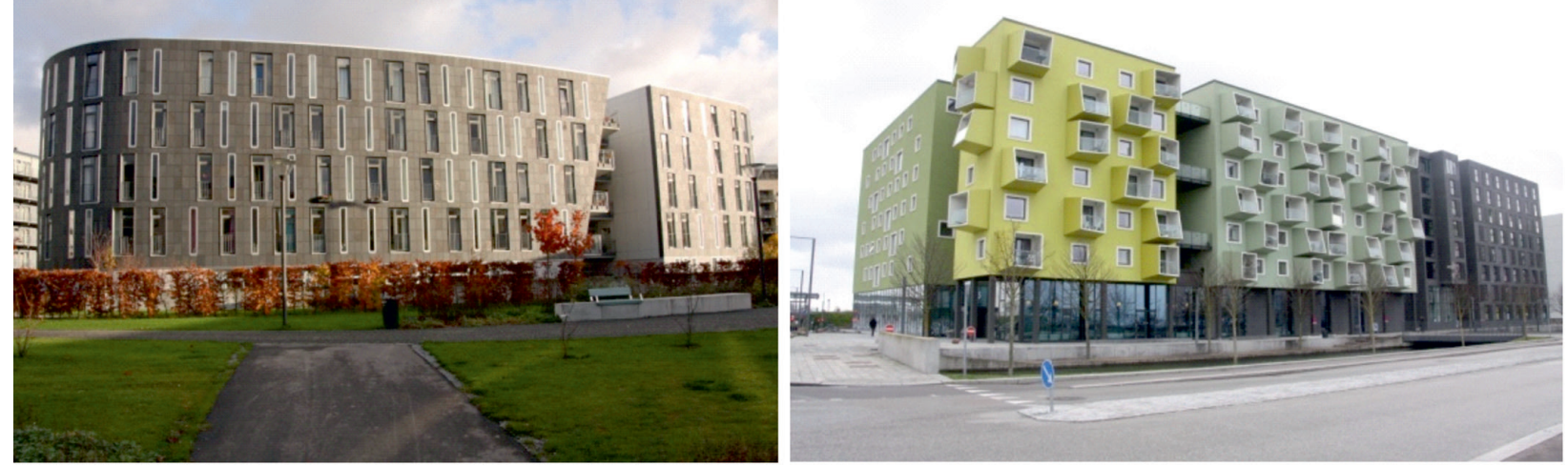

il. 2. Zespoły mieszkaniowe dla seniorów włączone w zabudowę mieszkaniową dla innych pokoleń w Kopenhadze: a- Flintholm, b) Ørestad , autor: M. Strzelecka-Seredyńska.

ill. 2. Residential complexes for senior citizens, incorporated in the residential development addressed to other generations in Copenhagen: a. Flintholm, b. Ørestad, author: M. Strzelecka-Seredyńska

na zasadzie elementów dodanych (przykład: program "Parasites", Rotterdam, berlińskie domy prefabrykowane Loftcube, duński program Soltag i Atika ${ }^{8}$ ).

Do omawianych rozwiązań zaliczyć można również wszelkie działania punktowe polegające na wprowadzaniu w istniejącą tkankę nowych jednostek o funkcji mieszkania, w tym łączących różne pokolenia (przykład: budynek wielorodzinny w Straubing, Niemcy, domy seniora w Frederiksbergu (Flintholm) i w Ørestad w Kopenhadze (Strzelecka-Seredyńska, 2017, s. 50, 54). Recycling przestrzeni w mikroskali wyraża się też w uzupełnianiu istniejącej zabudowy mieszkaniowej różnego typu strefami usług i rekreacji w formie przeszklonych zadaszeń, atriów, dziedzińców, oranżerii i pasaży.

Do czwartej grupy rozwiązań (recykling przestrzeni w makroskali) zaliczyć można wszystkie, powstające bardzo licznie w ostatnich dziesięcioleciach w Europie, realizacje dotyczące rewitalizacji terenów śródmiejskich. Za przykłady wzorcowe uznać należy, m.in. takie realizacje jak zespół mieszkaniowy Øster Fælled w Kopenhadze, Bo01 - City of Tomorrow w Malmö, Hammarby Sjöstad w Sztokholmie, doki w Amsterdamie oraz szereg późniejszych realizacji ${ }^{9}$. $Z$ uwagi na odniesienie się $w$ ramach rewitalizacji terenów śródmiejskich do realizacji idei miasta uniwersalnego i zrównoważenia społecznego (m.in. łączenie pokoleń) należy zwrócić uwagę na koncepcję m.in. socjalnego osiedla Gyldenrisparken w Kopenhadze oraz rewitalizację terenów po-portowych w Malmö z wprowadzonymi w zabudowę mieszkaniami dla seniorów- Neptuna (Strzelecka-Seredyńska, 2020, s.127, 131).

\section{Podsumowanie}

Przedstawiony wyżej, w syntetycznej formie, materiał oparto na autorskiej analizie wybranych przykładów zabudowy mieszkaniowej, zrealizowanej w ostatnich dwu dekadach. Wpisują się one harmonijnie, na różnych zasadach, w środowisko naturalne.

Przyjmując, jako kryterium oceny rozwiązań, odniesienie się do zasad oszczędnej gospodarki terenem i pozyskiwania wszelkich rezerw przestrzeni na rzecz programu mieszkaniowego w mieście, wyodrębniono różne możliwości działań. Należą do nich m.in. propozycje wprowadzania innowacyjnych form zabudowy, a także zwiększania jej intensywności. Promuje się recykling przestrzeni w drodze uzupełniania istniejącej tkanki oraz jej sanacji oraz działania rewitalizacyjne na obszarach zdegradowanych.

Wymienione rozwiązania mają miejsce w ramach wdrażania procesów reurbanizacji (rozwój „do wewnątrz") na terenach śródmiejskich, a także w powstających nowych dzielnicach, osiedlach i zespołach mieszkaniowych. Należy tu dodać, że adjusted to being incorporated in it by adding certain components (e.g.: the 'Parasites' programme, Rotterdam; Loftcube - prefabricated houses in Berlin; the Danish programmes of Soltag and Atika $\left.{ }^{8}\right)$.

This type of solutions also includes all sorts of localised measures, consisting in introducing new residential units, including ones addressed to different generations, in the existing tissue (e.g.: a multi-family building in Straubing, Germany; homes for the elderly in Frederiksberg (Flintholm) and in Ørestad, Copenhagen (Strzelecka - Seredyńska, 2017, pp. 50, 54)). Space recycling in microscale finds its manifestation in adding all sorts of services and recreation facilities in existing residential buildings, taking the form of glazed canopies, atria, courtyards, winter gardens, and passages. The fourth group of solutions (macroscale space recycling) includes projects focusing on the revitalisation of inner cities, mushrooming in Europe in recent decades. Model examples of such projects are e.g.: the residential complex Øster Fælled in Copenhagen, Bo01 - City of Tomorrow in Malmö, Hammarby Sjöstad in Stockholm, the docks in Amsterdam, and a number of later projects ${ }^{8}$. Due to the fact that inner-city revitalisation projects make a reference to implementing the concept of the universal city and social sustainability (connecting generations), emphasis should be put on the social housing estate Gyldenrisparken in Copenhagen and revitalisation of post-port areas in Malmö, with apartments for senior citizens introduced in the existing development - Neptuna (Strzelecka-Seredyńska, 2020, pp.127, 131).

\section{Summary}

The material presented in a synthetic form in the article is based on the author's analysis of selected examples of residential buildings harmoniously incorporated into the natural environment in different ways implemented in the last two decades were analysed.

The activities related to re-urbanization seem to be important due to the economical use of the area and the acquiring of all reserves of space for the housing program in the city. They are aimed at activating downtown areas and creating an attractive living environment for all generations.

Assuming that the contemporary city plays a key role not only in the implementation of eco-development, but also sustainable development, this paper attempts to emphasise not only the relations between the housing environment and nature, but also the implementation of the concept of universal residential space, emerging as a result of socially sustainable architecture and urban planning. This has been manifested in decisions concerning the need to bring together apartments for different generations in one complex or in 
pierwsza wymieniona grupa rozwiązań ma przede wszystkim na celu aktywizację terenów śródmiejskich i podniesienie ich atrakcyjności jako miejsca zamieszkania.

Przyjmując, że współczesne miasto pełni kluczową rolę nie tylko w realizacji koncepcji ekorozwoju, ale również rozwoju zrównoważonego, w przedstawionym materiale starano się zwrócić uwagę również na, towarzyszące omówionym rozwiązaniom, odniesienie się również do zasad kreowania uniwersalnej przestrzeni do mieszkania służącej zrównoważeniu społecznemu. Znajduje to wyraz w łączeniu, we wspólnej zabudowie lub na wspólnym terenie, mieszkań dla różnych generacji. Świadczą o tym, przytoczone wyżej, przykłady wprowadzania mieszkań dla seniorów na obszary śródmiejskie w ramach działań reurbanizacyjnych. Rozwiązania te stanowią odpowiedź na obserwowane obecnie zmiany demograficzne, w tym procesy starzenia się mieszkańców miast europejskich.

Ogólnie należy podkreślić, że przed miastem XXI wieku stoi szereg nowych wyzwań i oczekiwań związanych z ewoluowaniem jego przestrzeni i poszukiwaniem rozwiązań wpisujących się w konieczność ochrony środowiska naturalnego oraz oczekiwania mieszkańców związane z jakością życia i standardem mieszkania.

\section{PRZYPISY}

'W przybliżeniu ok. 350 mln osób zamieszkuje aglomeracje miejskie liczące ponad 5000 mieszkańców.

2 Pierwsze oznaki suburbanizacji miały miejsce już ponad sto lat temu. Procesy dezurbanizacyjne pojawiły się jako kolejna faza opuszczania miasta przez mieszkańców. Jedną z odpowiedzi na wymienione, niekorzystne tendencje $w$ rozwoju miast jest idea reurbanizacji.

3 Idea Cittaslow, związana z potencjałem małych miast liczacych do 50000 mieszkańców, powstała we Włoszech (1998 rok). Polskie miasta przystąpiły do niej w 2006 roku.

${ }^{4}$ Wymienione formy zabudowy znane są w długiej historii architektury oraz budownictwa lokalnego na całym świecie.

5 Działania te mają miejsce na ogół na terenach wewnątrzmiejskich oczyszczanych z degradującej je zabudowy, m.in. przemysłowej, portowej, militarnej, kolejowej.

${ }^{6}$ Wymienione realizacje holenderskie oraz austriackie stanowiły przedmiot badań autorskich in citu na terenie Holandii i Austrii.

7 W Amsterdamie obecnie kilka tysięcy rodzin mieszka na pływających jednostkach. Domy na wodzie powstaja w wielu krajach i miastach-w Londynie, Berlinie, w USA, a ostatnio również w Polsce (m.in. w Mielnie, Unieściu, Ślesinie, Kryspinowie.

${ }^{8}$ Prototypowy domy prefabrykowane Soltag i Atika-mieszkania montowane na dachach.

${ }^{9}$ Nie omawia się szerzej w pracy przykładów rozwiązań z uwagi na liczne pozycje literatury dotyczące tematu rewitalizacji terenów śródmiejskich

\section{BIBLIOGRAFIA}

[1] Jakubczyk-Gryszkiewicz, J.,2012, w: Liszewski, S., red. Geografia urbanistyczna, Warszawa: PWN.

[2] Grzeszczak, J., 1996, Tendencje kontrurbanizacyjne w krajach Europy zachodniej, Warszawa: PAN.

[3] Miasta przyszłości. Wyzwania, wizje, perspektywy, 2011, Komisja Europejska, Dyrekcja Generalna ds. Polityki Regionalnej, Bruksela

[4] Nowa Karta Ateńska. Wizja miast XXI wieku, 2003, Lizbona

[5] Strzelecka-Seredyńska, M., 2017, Kształtowanie środowiska życia osób starszych i jego relacji z otoczeniem na przykładzie Kopenhagi, w: Czasopismo Techniczne 10 (114), Kraków: Wydawnictwo Politechniki Krakowskiej [6] Strzelecka-Seredyńska, M., 2018, Sustainable residential housing for senior citizens - contemporary projects, MATEC Web of Conferences, ECCE , vol 174

[7] Strzelecka-Seredyńska, M., 2020, Kształtowanie środowiska życia osób starszych we współczesnym mieście (praca doktorska)

[8] Wehle-Strzelecka, S., 2014, Energia słońca w kształtowaniu środowiska mieszkaniowego, Kraków: Wydawnictwo Politechniki Krakowskiej

[9] Wehle-Strzelecka, S., 2018, Contemporary built environment in the context of evolution of energy- efficient solutions in architecture, MATEC Web of Conferences, ECCE, vol 174

[10] Wehle-Strzelecka, S., 2018, Wspótczesne miasto europejskie - wyzwania, perspektywy i wizje rozwoju, Lwów, Wydawnictwo Narodowego Uniwersytetu „Lwowska Politechnika”, seria Architektura, nr 895

[11] Uytenhaak, R., 2008, Cities full of space qualities of density, Rotterdam: 010 publishers one area. The examples of introducing apartments for senior citizens in inner cities within the scheme of reurbanisation measures confirm this conclusion. Such solutions constitute an answer to the currently observable demographic changes, including the process of aging of city dwellers in Europe.

Furthermore, the study demonstrated that the city of the $21^{\text {st }}$ century faces a number of new challenges and expectations connected with the evolution of their spaces and the search of solutions in line with the need to protect the natural environment and the concept of urban ecology, as well as expectations of city inhabitants as to the quality of life and housing standards. Measures which are in line with processes of reurbanisation and renaissance of urban areas and opening towards the needs of city dwellers of all generations can be recognised as optimal solutions in the field of architecture and urban planning. Innovative concepts of obtaining land and recycling space by means of additions to the existing developments, increasing the intensity of the existing developments, and revitalisation of degraded inner-city zones.

\section{ENDNOTES}

Approximately 350 million people live in urban agglomerations with more than 5,000 inhabitants.

2 First symptoms of suburbanisation occurred already over one hundred years ago. Deurbanization processes appeared as the next phase of residents' leaving their cities. One of the responses to these trends is the idea of re-urbanization.

${ }^{3}$ The concept of Cittaslow, associated with the potential of towns with populations up to 50,000, originates from Italy (1998). Polish cities joined it in 2006.

${ }^{4}$ These forms have appeared in the long history of architecture and local construction worldwide.

5 Such measures are usually undertaken in inner cities in the process of cleansing them from architecture that degrades them e.g.: industrial, port, military, railway facilities.

6 These Dutch and Austrian projects constituted a subject of in situ studies in the Netherlands and Austria.

Several thousand families live in floating apartments in Amsterdam today. Houses on the water are erected in numerous countries and cities - in London, Berlin, in the USA, and recently in Poland, as well (e.g.: in Mielno, Unieść, Slesin, Kryspinów).

8 Prototypes of prefabricated houses; Soltag and Atika - apartments installed on roofs.

${ }^{9}$ Examples of solutions are not discussed in this paper due to numerous literature items devoted to the subject of revitalisation of inner cities.

\section{REFERENCES :}

[1] Jakubczyk- Gryszkiewicz, J., 2012, in: Liszewski, S., ed. Geografia urbanistyczna, Warsaw: PWN.

[2] Grzeszczak, J., 1996, Tendencje kontrurbanizacyjne w krajach Europy zachodniej, Warsaw: PAN.

[3] New Athens Charter. Vision of 21st-century Cities, 2003, Lisbon. [4] Miasta przyszłości. Wyzwania, wizje, perspektywy, 2011, Komisja Europejska, Dyrekcja, Generalna ds. Polityki Regionalnej, Bruksela. [5] Strzelecka-Seredyńska, M., 2017, Kształtowanie środowiska życia osób starszych i jego relacji z otoczeniem na przykładzie Kopenhagi, Czasopismo Techniczne 10 (114), Cracow: Publishing House of Cracow University of Technology

[6] Strzelecka-Seredyńska, M., 2018, Sustainable residential housing for senior citizens - contemporary projects, MATEC Web of Conferences, ECCE ,vol. 174

[7] Strzelecka-Seredyńska, M., 2020, Kształtowanie środowiska życia osób starszych we wspótczesnym mieście (Ph.D. thesis).

[8] Wehle-Strzelecka, S., 2014, Energia słońca w kształtowaniu środowiska mieszkaniowego, Cracow: Publishing House of Cracow University of Technology.

[9] Wehle-Strzelecka, S., 2018, Contemporary built environment in the context of evolution of energy-efficient solutions in architecture, MATEC Web of Conferences, ECCE, vol. 174

[10] Wehle-Strzelecka, S., 2018, Wspótczesne miasto europejskie wyzwania, perspektywy i wizje rozwoju, Lviv, Magazine of the National University, Lwowska Politechnika, series: Architektura, No. 895. [11] Uytenhaak, R., 2008, Cities full of space qualities of density, Rotterdam: 010 publishers 